this source, by the following simple procedure: After taking the first reading, place the finger over the upper end of the tube so as to close it, and remove the tube from the bottle. Discard the contents of the tube, wipe out the latter, return it to the bottle, and again fill it to the upper end, as before, with hot water; now centrifugate again, and add any fat thus found to the fat obtained at the first reading.

For testing cream, the method is identical, except that the larger calibered tube is used. For creams containing above 15 per cent. butter fat, the bottle will not give a reading if 5 c.c. of cream is used. In this case, fill the bottle with cream to the mark 2.5 , then with water to the mark 5, and finally to the mark 10 with acid, and proceed as before.

These bottles were made for me by Leitz, and may be obtained from him.

The following table, modified from Holland's "Medical Chemistry and Toxicology," will be found useful in judging the quality of a sample of milk:

\begin{tabular}{|c|c|c|c|c|}
\hline \multicolumn{2}{|c|}{ Milk. } & Sp. g. & $\begin{array}{l}\text { Percentage } \\
\text { of butter } \\
\text { fat. }\end{array}$ & Proteids and Quality. \\
\hline \multicolumn{2}{|c|}{$\begin{array}{l}\text { Normal average } \\
\text { Healihy variations }\end{array}$} & $\begin{array}{l}1.031 \\
1.028-1.029\end{array}$ & $\begin{array}{l}3.5 \\
4.5-6 \\
2.5-3\end{array}$ & $\begin{array}{l}\text { Normal (rich milk) } \\
\text { Normal (fair milk) }\end{array}$ \\
\hline Unhealthy & " & Below 1.0:8 & Above 5.0 & Normal or slightly below \\
\hline "4 & “ & " $\quad 1.028$ & $2.5-5$ & \\
\hline ". & " & Above 1.033 & $\begin{array}{l}\text { Below } 2.5 \\
\text { A bove 5.0 }\end{array}$ & $\begin{array}{l}\text { Very low (very poor) } \\
\text { Very high (very rich) }\end{array}$ \\
\hline "“ & " & " 1.083 & $2.5-5$ & High \\
\hline "” & "، & " 1.033 & Below 2.5 & Normal or nearly so. \\
\hline
\end{tabular}

\section{A CASE OF CRETINISM WITH SPONTANEOUS IMPROVEMENT.}

\section{ELEANORA S. EVERHARD, M.D. \\ DAYTON, OHIO.}

This case is reported because it is interesting and encouraging, in view of the slight tendency to spontaneous improvement in cretinism.

Patient.-A girl, aged 12.

Fanily History.- The father had chronic nephritis, in an advanced stage, when the child was born. On the maternal side the history is negative. There is no history of cretinism or mental defect. The patient is the youngest of four children. The sister has never been strong, but gives no history of organic lesions. One brother has asthma; a second brother is excessively nervous. Nine years elapsed between the birth of the second brother and the patient.

Previous History.-As an infant, the patient slept much and cried little. The first teeth were not markedly late in appear ing, but were very irregular. The child walked at two and one-half years. The hair was stiff and straight. The skin easily roughened, with a tendency to eczema. The eyes were slightly oblique, so that friends called her a "little Jap." The abdomen was enlarged but not pendulous, the navel slightly protruding. The child easily became cold, even to blueness of skin. Bowels were either constipated or very loose. The appetite was fair. When a few months old the child had an abscess back of one ear. Later she had "ulcerated sore throat." Adenoid growths were removed at about the sixth year. No mental change followed. In the winter of 1903 she had pneimonia. The temperature was so low and the child so little ill that a physician was not called for several days. In 1904 she had measles.

At the sixth year the child was sent to kindergarten. In neither public nor private schools could she be taught. At the tenth year she could not even be depended on to go to school. She would linger on the way, not realizing that she was disobedient. Conversation was incoherent and irrelevant.
She could not dress or care for herself. Menstruation began at about ten years and eight months, and from that time the periods have occurred at regular intervals, duration four days. There is no pain with the exception of an occasional headache. The child began to brighten intellectually and can now read in the second reader and wants to learn everything she sees done. Conversation is better and she is beginning to care for herself. The abdomen has receded.

Examination.-I first examined the patient in August, 1905; she was suffering from acute indigestion. Temperature was 99 ; pulse, 88 ; height, 4 ft. $7 \frac{3}{8}$ in.; weight, $85 \frac{3}{4}$ lbs. While height and weight were normal, the patient presented the appearance of being short and broad. The hands, fingers, and feet, were broad; the abdomen was large; gait was somewhat awkward; the lower part of the face was heavy. The expression was one of curiosity, but of no intelligent interest. The skin was harsh and somewhat eczematous, though perspiring freely because of the midsummer heat. Back of the right ear and about the nostrils, the skin was red and moist. The hair was fairly soft and somewhat curly. The tonsils and pharynx were congested. The thyroid gland was very small.

The patient obeyed directions inaccurately. both because of lack of comprehension and because of inability to act. Conversation was irrelevant, but not incoherent. She was restless, constantly moving about. The urine was normal. The patient was able to come some distance to the office, alone, after the first few times, when she had learned the way. She takes cold easily.

Treatment.-Thyroid extract was prescribed, gr. 1/2 t. i. d., increasing every other day until grs, vi were taken. Later this amount was increased to grs. viii. At the end of seven weeks the child had grown a little over one inch and had gained two pounds in weight. The lower part of the face had become less heavy. The expression was one of interest rather than of curiosity. She obeyed directions more quickly and exactly and could remember messages. She talked more intelligently, sat quietly in the presence of others, and her teacher says that in two weeks there was a noticeable increase in her ability to memorize.

From the appearance of the child, as seen on the street, and the history, together with the conditions as found on examination, I draw the following conclusions:

The patient presented a case of cretinism, coincident with adenoid growths. With the beginning of menstruation, there was a marked spontaneous improvement, the rapidity of which was greatly increased under treatment with thyroid extract.

\section{AN TMPROVED CAUTERY TIP OTIS ORENDORFF, M.D. CANON CITY, COLO}

In cauterizing the inferior turbinate the success of the operation depends on the cut being deep and clean in order that the resulting cicatrix will produce sufficient contraction of the interturgescent tissues without destruction of the functions. When the action of a saw or bread knife is thought of, a glance at the illustration will at once suggest its utility. By use of very slight pressure and a little to and from mo-

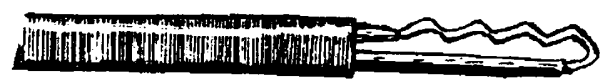

tion this tip will bury itself into the tissues as if they were lutter. In addition to the saw principle the form of the knife seems to retain the heat, permitting absolute control and preventing the distressing tearing and hemorrhage that frequently accompany the cautery operation. I apply the knife cold and do not remove it until again cooled. Any jeweller can remodel the orrinary tip to this shape. 